\title{
GMR
}

\section{Agrobacterium-mediated transformation of Fusarium proliferatum}

\author{
J. Bernardi-Wenzel ${ }^{1}$, M.C. Quecine ${ }^{2}$, J.L. Azevedo ${ }^{1}$ and J.A. Pamphile ${ }^{1}$ \\ ${ }^{1}$ Laboratório de Biotecnologia Microbiana, Departamento de Biotecnologia, \\ Genética e Biologia Celular, Universidade Estadual de Maringá, Maringá, PR, \\ Brasil \\ ${ }^{2}$ Escola Superior de Agricultura Luiz de Queiroz, Universidade de São Paulo, \\ Piracicaba, SP, Brasil \\ Corresponding author: J. Bernardi-Wenzel \\ E-mail: juliber22@gmail.com \\ Genet. Mol. Res. 15 (2): gmr. 15027944 \\ Received October 28, 2015 \\ Accepted December 10, 2015 \\ Published June 3, 2016 \\ DOI http://dx.doi.org/10.4238/gmr.15027944
}

\begin{abstract}
Fusarium proliferatum is an important pathogen that is associated with plant diseases and primarily affects aerial plant parts by producing different mycotoxins, which are toxic to humans and animals. Within the last decade, this fungus has also been described as one of the causes of red root rot or sudden death syndrome in soybean, which causes extensive damage to this crop. This study describes the Agrobacterium tumefaciens-mediated transformation of $F$. proliferatum as a tool for the disruption of pathogenicity genes. The genetic transformation was performed using two binary vectors (pCAMDsRed and pFAT-GFP) containing the $h p h$ (hygromycin B resistance) gene as a selection marker and red and green fluorescence, respectively. The presence of acetosyringone and the use of filter paper or nitrocellulose membrane were evaluated for their effect on the transformation efficiency. A mean processing rate of $94 \%$ was obtained with $96 \mathrm{~h}$ of co-cultivation only in the presence of acetosyringone and the use of filter paper or nitrocellulose membrane did not affect the transformation process. Hygromycin B resistance and the presence of the $h p h$ gene
\end{abstract}


were confirmed by PCR, and fluorescence due to the expression of GFP and DsRed protein was monitored in the transformants. A high rate of mitotic stability (95\%) was observed. The efficiency of Agrobacteriummediated transformation of $F$. proliferatum allows the technique to be used for random insertional mutagenesis studies and to analyze fungal genes involved in the infection process.

Key words: Random insertional mutagenesis; Sudden death syndrome; Fluorescence; Green fluorescent protein; DsRed; Soybean

\section{INTRODUCTION}

Several species of Fusarium are responsible for causing disease in major crops, such as corn, soybean, and wheat, and more than $80 \%$ of cultivated plants are infected by species of this genus (Ivić et al., 2009). One of the most severe diseases is sudden death syndrome (SDS), first described in a Brazilian crop in 1981/82 (Yorinori et al., 1993). SDS is responsible for major losses in soybean and is of great importance in Brazil, which is an important grain producer in the world. SDS is caused by different species of the genus Fusarium, belonging to the Fusarium solani complex, which to date includes $F$. virguliforme, F. tucumaniae, $F$. crassistipitatum, F. cuneirostrum, and $F$. brasiliensis. More recently, this also includes $F$. proliferatum, which has been shown to cause disease of the aerial parts of different crops and its infection of soybean roots has been well described (Aoki et al., 2005; Díaz-Arias et al., 2011; Aoki et al., 2012; Chang et al., 2015).

F. proliferatum (Matsush.) Nirenberg, formerly Gerlach \& Nirenberg 1982, is a fungus with a worldwide distribution that is associated with different diseases in economically important plants such as corn, bananas, asparagus, wheat, barley, soybean and potato. It is of great importance due to the damage it causes to the plant directly and indirectly through the production of mycotoxins, such as moniliformin, bovericin, fusaric acid, fusaroproliferin, and fumonisins (Merlington et al., 2014). The best strategy to control infection is the production of plants that are resistant to the pathogen. Knowledge of the molecular interactions between the host plant and the fungus is critical so that pathogenic genes that can activate plant defense can be identified (Boller and He, 2009). The infection process requires the penetration of the host plant by the fungus, which then produces a series of smaller proteins and other molecules that activate effectors, which represent the host plant defense (Stergiopoulos et al., 2012).

The isolation of pathogenicity genes provides important information to understand the mechanisms of fungal infection. Different techniques have been used for this purpose, the most common being random insertional mutagenesis, which allows the integration of vector DNA into the fungus. This causes disruption of genes, including those causing pathogenicity, allowing them to be identified and their function to be elucidated (Mullins and Kang, 2001).

To perform random insertional mutagenesis, the most commonly used techniques are the physical transformation of protoplasts using electroporation and polyethylene glycol (PEG) (Ruiz-Díez, 2002) and biological methods such as Agrobacterium tumefaciensmediated transformation (ATMT). ATMT was initially was only used for plants but has been increasingly used in recent decades to transform other species, including filamentous fungi (de Groot et al., 1998; Malonek and Meinhardt, 2001; Rodrigues et al., 2013). The A. tumefaciens-mediated transformation of filamentous fungi has been performed due to its 
technical ease of execution, high transformation efficiency, and ability to generate random DNA integration into unique sites in the host genome (Mullins et al., 2001). Reports in the literature demonstrate the A. tumefaciens-mediated transformation of different Fusarium species; however, there is no report of the genetic transformation of $F$. proliferatum. The use of ATMT could form the basis for Agrobacterium-mediated insertional mutagenesis and facilitate functional genomics studies in different organisms, in which genes interrupted by the insertion of exogenous DNA (plasmid) can be identified by amplifying and sequencing these regions to determine which genes are related to pathogenicity in different species (Liu and Chen, 2007).

Different protocols for the genetic transformation of fungi via A. tumefaciens exist; however, each method can result in different transformation efficiencies and requires a protocol adapted for the greatest efficiency in processing. Factors such as the strain used and the concentration of some reagents might positively or negatively affect the transformation process. The aim of this work was to develop an efficient $A$. tumefaciensmediated genetic transformation method for $F$. proliferatum using two reporter genes, containing either green fluorescent protein (GFP) or Discosoma species Red (DsRed) as markers, for future studies of host-pathogen interactions and use for insertional mutagenesis in plant-pathogen interactions.

\section{MATERIAL AND METHODS}

\section{Strains and plasmids}

To perform ATMT, a $F$. proliferatum strain acquired by the Biological Institute of São Paulo (MMBF 78/09) was used. The fungus was grown in potato dextrose agar (PDA) medium. The disarmed strains of $A$. tumefaciens EHA105 containing the plasmid pFAT-GFP and pCAM-DsRed were kindly provided by Dr. Carlos Labate (Department of Genetics, College of Agriculture "Luiz de Queiroz", University of São Paulo, Piracicaba, Brazil).

The binary transformation vector pFAT-GFP (Fitzgerald et al., 2003) was kindly provided by Kim M. Plummer (PlantIndustry CSIRO, Australia). This binary vector of 18,422 bp contains the T-DNA region, the hygromycin B resistance gene ( $h p h)$ from Escherichia coli driven by the promoter of the glyceraldehyde-3-phosphate dehydrogenase gene (gpd) from Glomerella cingulata, and the $g f p$ gene from the jellyfish Aequorea victoria. The binary transformation vector pCAM-DsRed (Eckert et al., 2005) was purchased from the Fungal Genetics Stock Center. This binary vector of 12,008 bp includes the T-DNA region, the hygromycin B resistance gene ( $h p h)$ from $E$. coli driven by the promoter of the glyceraldehyde3-phosphate dehydrogenase gene (PgpdA) from Aspergillus nidulans, and the gene for the red fluorescent protein, DsRed, from the coral Discosoma sp.

\section{Morphology-based characterization and identification}

The fungus $F$. proliferatum, previously identified as $F$. solani f. sp Glycines, were cultivated in PDA medium and the micro-culture technique was used to identify microscopic structures. The cytological and morphological characteristics of endophytes were challenged by the identification keys (Nelson et al., 1983). 


\section{DNA extraction}

Genomic DNA was extracted using the DNA Isolation Kit Power Soil ${ }^{\circledR}$ (Mobio Laboratories Inc., USA) according the manufacturer instructions. The DNA concentration was estimated by comparison with DNA standards by electrophoresis on a $1 \%$ agarose gel. The DNA samples were stored at $-20^{\circ} \mathrm{C}$.

\section{Amplification and purification of internal transcribed spacer (ITS) of ribosomal DNA (rDNA)}

The fragments of ITS1-5.8S-ITS2 were amplified by primers ITS1 and ITS4 (White et al., 1990). The amplification of ITS regions of rDNA followed the methodology of Magnani et al. (2005). The amplified fragments were analyzed by $1 \%$ agarose gel electrophoresis. The products of amplification of ITS1-5.8S-ITS2 region of rDNA of the endophyte fungi strains were purified with GFX PCR DNA and the Gel Band Purification Kit (Amersham Biosciences, USA).

\section{Sequencing of the rDNA ITS regions}

Sequencing of the rDNA ITS1-5.8S-ITS2 region was done as published in Magnani et al. (2005). The amplification was performed in a MJ thermocycler (PTC-100, MJ Research, Inc., Canada) and the sequencing was done in an ABI-Prism 3500 Genetic Analyzer (Applied Biosystems, USA). The fungus was identified by analysis of DNA sequences of ITS1-5.8SITS2. A BLAST search was used to find the closest matched sequences in the GenBank database. Fungi sequences employed by the authors are aligned with Bioedit software (USA).

\section{F. proliferatum sensitivity test to hygromycin B}

To select for transformants after genetic transformation, the $F$. proliferatum lineage was evaluated to determine the minimum inhibitory concentration (MIC) of hygromycin B at which fungal growth is inhibited. Five replicates were used (Petri dishes) to assess pathogen growth. The MIC value was used for the subsequent selection of transformants. To establish the MIC, the fungal strain was inoculated onto Petri dishes containing PDA medium supplemented with increasing concentrations of hygromycin $\mathrm{B}(0,25,50,75,100,150$, and $200 \mathrm{mg} / \mathrm{mL})$ and were incubated for 21 days at $28^{\circ} \pm 2^{\circ} \mathrm{C}$ in the dark. The sensitivity to hygromycin B was estimated based on mycelial growth (colony radius in $\mathrm{cm}$ ) and the pathogen growth curve containing the area of the colony multiplied by the concentration of hygromycin $\mathrm{B}$. The concentration that prevented fungal growth was considered as the MIC concentration.

\section{A. tumefaciens-mediated transformation of $\boldsymbol{F}$. proliferatum}

A. tumefaciens-mediated transformation of $F$. proliferatum was performed with modifications of the methods of De Groot et al. (1998), Fitzgerald et al. (2003), and Rodrigues et al. (2013). The effect of two factors on the efficiency of transformation was assessed: the addition acetosyringone and the use of nitrocellulose membrane or filter paper. The $A$. tumefaciens cultures containing the vector pFAT-GFP (Fitzgerald et al., 2003) or pCAMDsRed (Eckert et al., 2005) were incubated at $26^{\circ} \pm 2^{\circ} \mathrm{C}$ for $24 \mathrm{~h}$ in $25 \mathrm{~mL}$ YEP medium $(10 \mathrm{~g}$ 
yeast extract, $10 \mathrm{~g}$ peptone, $5 \mathrm{~g} \mathrm{NaCl}, 15 \mathrm{~g}$ agar, $1000 \mathrm{~mL}$ distilled water; $\mathrm{pH}$ 7.0) containing $300 \mathrm{mg} / \mathrm{mL}$ streptomycin and $100 \mathrm{mg} / \mathrm{mL}$ rifampicin with stirring at $200 \mathrm{rpm}$. The cells of A. tumefaciens were then each diluted to reach an optical density of 0.2 at $600 \mathrm{~nm}\left(\mathrm{OD}_{600}\right)$ with liquid inducing medium (IM) $\left(10 \mathrm{mM} \mathrm{K}_{2} \mathrm{HPO}_{4}, 10 \mathrm{mM} \mathrm{KH}_{2} \mathrm{PO}_{4}, 2.5 \mathrm{mM} \mathrm{NaCl} ; 2 \mathrm{mM}\right.$ $\mathrm{MgSO}_{4} ; 0.7 \mathrm{mM} \mathrm{CaCl}_{2} ; 9 \mu \mathrm{M} \mathrm{FeSO}_{4} ; 4 \mathrm{mM} \mathrm{NH}_{4} \mathrm{SO}_{4} ; 10 \mathrm{mM}$ glucose, $0.5 \%$ glycerol, $\mathrm{pH}$ 5.3). Following autoclaving, $40 \mathrm{mM} 2$-(N-morpholin) ethanesulfonic acid was added, and the solution was sterilized by filtration, with or without the addition of $200 \mu \mathrm{M}$ acetosyringone, and the cultures were incubated for $6 \mathrm{~h}$ at $26^{\circ} \pm 2^{\circ} \mathrm{C}$ until the $\mathrm{OD}_{600}$ reached 0.6. The mycelium was grown and used to prepare a solution containing $10^{6} \mathrm{spores} / \mathrm{mL}$ in PDA containing $150 \mathrm{mg} /$ $\mathrm{mL}$ hygromycin $\mathrm{B}$, and the suspension was incubated at $28^{\circ} \pm 2^{\circ} \mathrm{C}$ for about $6 \mathrm{~h}$. Suspensions of $A$. tumefaciens and F. proliferatum were then mixed, and $20 \mu \mathrm{L}$ of each resulting suspension was placed onto pieces of filter paper (J. Prolab, Brazil) or nitrocellulose membranes (BioRad, USA) in Petri dishes containing MI, in the presence or absence of acetosyringone ( $200 \mu \mathrm{M})$. The Petri dishes were incubated at $28^{\circ} \pm 2^{\circ} \mathrm{C}$ for $96 \mathrm{~h}$. The filter paper fragments were then transferred to Petri dishes containing PDA medium containing $150 \mathrm{mg} / \mathrm{mL}$ hygromycin B and $300 \mathrm{mg} / \mathrm{mL}$ sodium cefoxitin.

\section{Selection of transformants}

Following the processing procedure, the fungi were tested using growth medium containing the MIC of hygromycin B, which inhibits the growth of non-transformed fungus. Fungal colonies that grew were considered to be transformants.

\section{Molecular analysis of transformants}

For the molecular analysis of the transformants, DNA extraction was performed. The transformed fungi were transferred to Petri dishes containing $20 \mathrm{~mL}$ liquid PDA medium and $150 \mathrm{mg} / \mathrm{mL}$ hygromycin B. The Petri dishes were incubated at $28^{\circ} \pm 2^{\circ} \mathrm{C}$ for $72-96 \mathrm{~h}$ and mycelia were then collected with a spatula, transferred to a Petri dish, and washed with sterile distilled water. The mycelia were then dried on autoclaved filter paper.

Genomic DNA was extracted using the DNA Isolation Kit Power Soil ${ }^{\circledR}$ (Mobio Laboratories Inc.) according to the manufacturer instructions. The DNA concentration was estimated by comparison with DNA standards by electrophoresis on a $1 \%$ agarose gel. The DNA samples were stored at $-20^{\circ} \mathrm{C}$.

For the molecular evaluation of the transformants, polymerase chain reaction (PCR) amplification was performed with a fragment of the $h p h$ gene from each plasmid using the oligonucleotides hph1 (5'-TTCGATGTAGGAGGGCGTGGAT-3') and hph2 (5'-CGCGTCTGCTGCTCCATACAAG-3') (Malonek and Meinhardt, 2001). The reaction was carried out using $0.2 \mathrm{mM}$ dNTPs, $3.7 \mathrm{mM} \mathrm{MgCl}, 0.05 \mu \mathrm{L} 1 \mathrm{X}$ buffer, $1 \mathrm{U}$ Taq polymerase, $0.2 \mathrm{mM}$ each primer, $10 \mathrm{ng}$ DNA, and ultra-pure water in a volume of 20 $\mu \mathrm{L}$. The amplification program consisted of an initial denaturation step of $5 \mathrm{~min}$ at $94^{\circ} \mathrm{C}$; 30 cycles of $1 \mathrm{~min}$ denaturation at $94^{\circ} \mathrm{C}, 1 \mathrm{~min}$ for primer annealing at $60^{\circ} \mathrm{C}, 1 \mathrm{~min}$ polymerization at $72^{\circ} \mathrm{C}$; and a final extension of $7 \mathrm{~min}$ at $72^{\circ} \mathrm{C}$. The amplicons were visualized on a $1.4 \%$ agarose gel to confirm the presence of the plasmid-specific genes in the transformed strain. 


\section{Analysis of transformants by fluorescence microscopy}

The transformants obtained by genetic transformation were cultured on new plates containing selective medium (PDA plus hygromycin B) and monosporic colonies were obtained. The transformants were then observed using a fluorescence microscope (Olympus BX51, Japan) using the FITC filter $(480 \mathrm{~nm})$ for transformants containing the pFAT-GFP plasmid and a TRITC filter $(545 \mathrm{~nm})$ for transformants containing the plasmid pCAM-DsRed. The green and red fluorescence of hyphae were imaged by a camera attached to the microscope using Spectral Imaging software (Carl Zeiss, Germany).

\section{Evaluation of transformants for mitotic stability}

To assess the mitotic stability of the transformants, the method described by Rodrigues et al. (2013) was used. Mycelial fragments of $F$. proliferatum were inoculated onto PDA medium containing $150 \mathrm{mg} / \mathrm{mL}$ hygromycin $\mathrm{B}$ and were incubated for seven days at $28^{\circ} \pm$ $2^{\circ} \mathrm{C}$. Fragments of the developed colonies were then transferred to Petri dishes containing PDA medium and were incubated for seven days at $28^{\circ} \pm 2^{\circ} \mathrm{C}$. This process was repeated five times in total. Fragments of colonies from the fifth subculture were transferred to Petri dishes containing PDA medium and $150 \mathrm{mg} / \mathrm{mL}$ hygromycin B and were incubated for seven days at $28^{\circ} \pm 2^{\circ} \mathrm{C}$. The number of transformants that were still resistant to hygromycin $\mathrm{B}$ was then estimated according to their continued growth in selective medium.

\section{RESULTS}

\section{Identification of the fungus}

The identity of the fungus was confirmed using the identification keys and the regions ITS1, ITS2 and 5.8S rDNA, as similar to the fungus deposited in GenBank for F. proliferatum (HQ38763.1).

\section{Sensitivity of $F$. proliferatum to hygromycin B}

In the sensitivity test to determine the MIC of hygromycin B, the growth of $F$. proliferatum was partially inhibited at concentrations of 50,75 and $100 \mathrm{mg} / \mathrm{mL}$ and growth was completely inhibited at concentrations greater than $150 \mathrm{mg} / \mathrm{mL}$. The MIC concentration was thus determined as $150 \mathrm{mg} / \mathrm{mL}$ hygromycin B and this was then used for the selection of transformants.

\section{Genetic transformation of $\boldsymbol{F}$. proliferatum and mitotic stability}

A. tumefaciens-mediated transformation of $F$. proliferatum using two different plasmids and following $96 \mathrm{~h}$ of co-cultivation occurred only in the presence of acetosyringone. In the absence of acetosyringone, no genetic transformation of the fungus occurred. On average, the transformation efficiency was $98 \%$ for the pFAT-GFP plasmid and $90 \%$ for pCAMDsRed plasmid (three independent transformation experiments). This yielded a total of 451 
transformants, which corresponded to approximately $3 \%$ of yeast genes according to the mean number of genes present in other species of Fusarium that have been sequenced. The use of filter paper or nitrocellulose membrane did not affect the transformation efficiency.

From the transformants that were obtained and assessed for mitotic stability, an average of $95 \%$ of transformants were mitotically stable for resistance to hygromycin B at a concentration of $150 \mathrm{mg} / \mathrm{mL}$ after five generations.

\section{Confirmation of the integration of the $h p h$ gene into the genome of the fungus}

The integration of the $h p h$ gene, which confers resistance to hygromycin B and was present within the two plasmids used for genetic transformation, into the genome of $F$. proliferatum was confirmed by amplifying a fragment of $600 \mathrm{bp}$ of the $h p h$ gene by PCR (Figure 1).The presence of the $h p h$ gene was confirmed in all hygromycin B-resistant transformants on selective medium, indicating that all the transformants contained plasmid DNA.

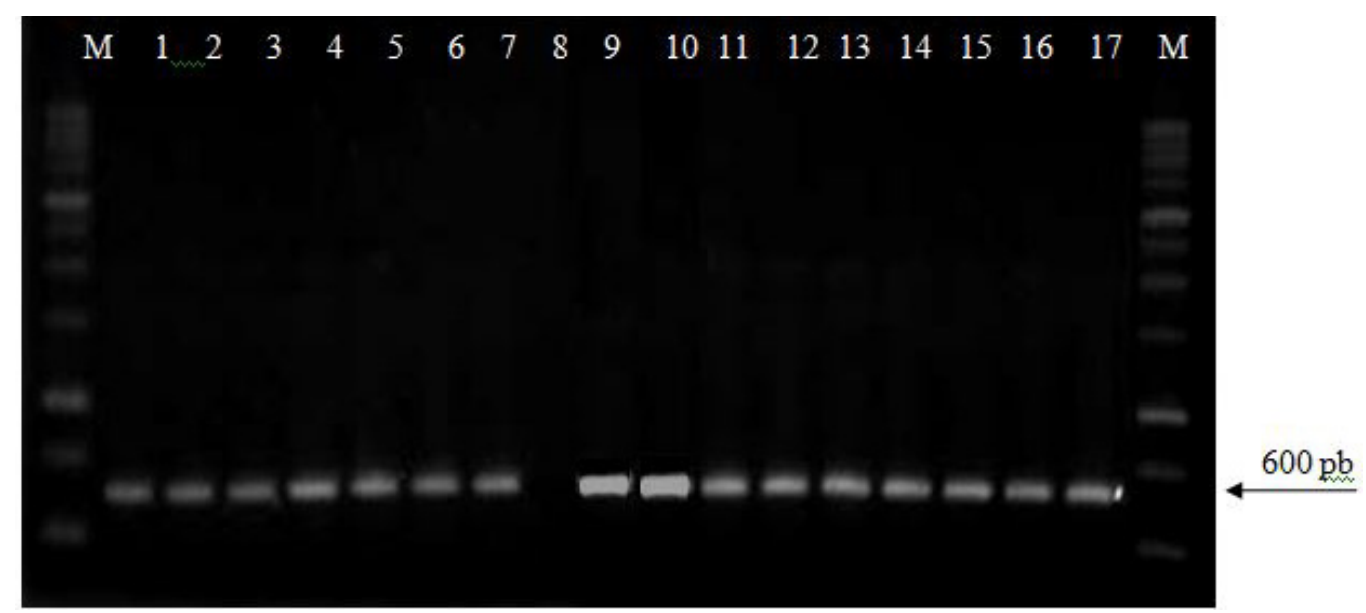

Figure 1. Detection of the $h p h$ gene, which confers hygromycin B resistance to transformants, by PCR amplification using primers hph1 and hph2. Lane M: 1-kb DNA ladder; lanes 1-7: transformants containing the plasmid pFATGFP; lane 8: wild-type fungus; lane 9: pFAT-GFP plasmid; 10: pCAM-DsRed plasmid; lanes 11-17: transformants containing the pCAM-DsRed plasmid.

\section{Expression of GFP and DsRed proteins}

The selected hygromycin B-resistant transformant colonies were observed using fluorescence microscopy for the expression of GFP fluorescent protein for transformants with the pFAT-GFP plasmid and expression of DsRed for transformants with pCAM-DsRed plasmid (Figure 2). Fluorescence was monitored in the colonies that underwent the mitotic stability test after several generations on non-selective medium. There was no variation in the expression of the proteins regardless of the number of generations. The untransformed wildtype fungal lineage showed no fluorescence. 


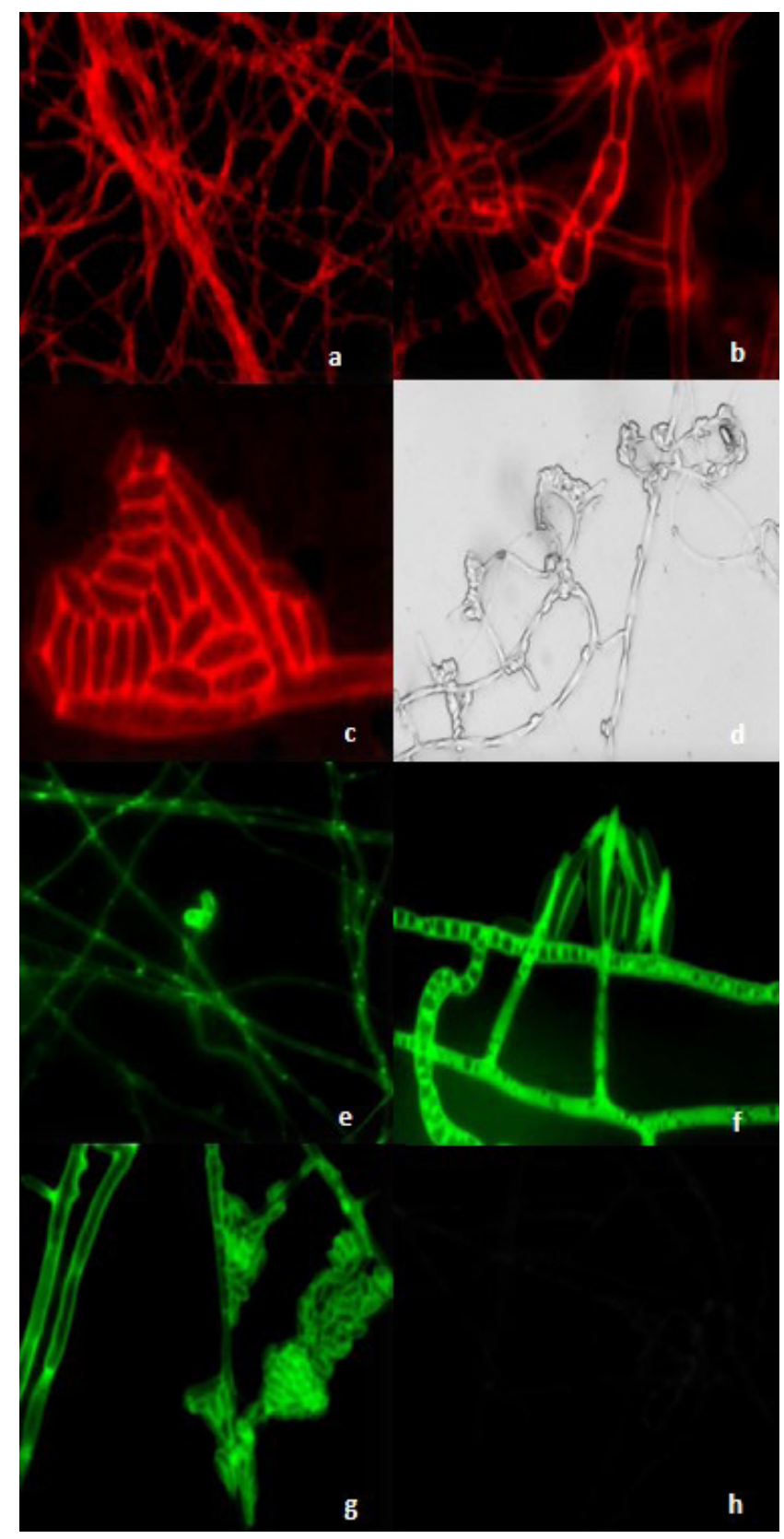

Figure 2. Fluorescence microscopy of Fusarium proliferatum transformants expressing fluorescent protein genes. a.-c. Hyphae and conidia of fungi transformed with Agrobacterium tumefaciens containing the plasmid pCAMDsRed with expression of red fluorescent DsRed. e.-g. Hyphae and conidia of fungi transformed with A. tumefaciens containing the plasmid pFAT-GFP with expression of green fluorescent GFP. $\mathbf{d}$. and $\mathbf{h}$. Hyphae and conidia of wildtype fungus observed using optical microscopy and fluorescence, respectively. In $\mathbf{a}, \mathbf{d}, \mathbf{e}$, and $\mathbf{h}$ : 40X magnification; $\mathbf{b}, \mathbf{c}, \mathbf{f}$, and $\mathbf{g}$ : 100X magnification. 


\section{DISCUSSION}

Similar to other species of fungi and plants, A. tumefaciens-mediated transformation can also be successfully applied to $F$. proliferatum. A high mean transformation efficiency of $94 \%$ after $96 \mathrm{~h}$ of co-culture was achieved with a greater ease of implementation and lower cost compared to other techniques. Similar to Phyllosticta citricicarpa, F. proliferatum does not exhibit rapid growth. The initial amount of $10^{6}$ conidia in the inoculum was sufficient to generate a satisfactory number of transformants. These results corroborate the findings of Islam et al. (2012), who optimized the Agrobacterium-mediated transformation of F. oxysporum f. sp ciceri, and also found $10^{6}$ to be a suitable amount of initial inoculum. According to De Groot (1998), the frequency of transformation varies among species, some of which are more susceptible to Agrobacterium-mediated transformation.

Although the literature contains no report of the transformation of $F$. proliferatum, other species of the genus Fusarium have been transformed via $A$. tumefaciens, such as $F$. circinatum (Covert et al., 2001), F. graminearum (Lysøe et al., 2006), F. oxysporum (Mullins et al., 2001; Lakshman et al., 2012), F. culmorum (Michielse et al., 2005), F. solani (Liu and Bao, 2009), F. equiseti (Maciá-Vicente et al., 2009), F. virguliforme (Pudake et al., 2013) and F. avenaceum (Sørensen et al., 2014). In these studies, the presence of acetosyringone led to a more efficient transformation. A concentration of $200 \mu \mathrm{M}$ acetosyringone was suitable for processing since no transformants were obtained in the absence of acetosyringone. This was due to the expression of vir genes, which are stimulated in the presence of acetosyringone, that are responsible for the integration of the exogenous DNA of the fungus, increasing the efficiency of transformation (Sebastianes, 2010). For each species, despite similar processing conditions, the choice of the $A$. tumefaciens strain, the construction of appropriate vectors, and other adaptations to the protocol might be required to obtain a satisfactory transformation rate (Frandsen, 2011). This was the primary goal of this study for F. proliferatum.

No significant differences were observed in the number of transformants with the use of either filter paper or nitrocellulose membrane. Therefore, filter paper can be used instead of nitrocellulose membrane, resulting in a lower cost. Similar results were also obtained by Covert et al. (2001), where they used genetically transformed $F$. circinatum. Michielse et al. (2005) concluded that depending on the species, genetic transformation efficiency is not improved by the use of Hybond nitrocellulose membrane over the use of filter paper, confirming the low cost of processing associated with transformation. The optimal processing conditions for producing transformants of $F$. proliferatum via $A$. tumefaciens, which should be used for future studies, are: the use of $10^{6}$ conidia as an initial amount of inoculum, the use of acetosyringone at a concentration of $200 \mu \mathrm{M}$, and the use of filter paper.

The resistance of $F$. proliferatum transformants to different hygromycin B concentrations $(0,25,50,75,100,150$, and $200 \mathrm{mg} / \mathrm{mL})$ was similar to that found for other species, such as F. graminearum (Lysøe et al., 2006) and F. virguliforme (Pudake et al., 2013), where a concentration of $150 \mathrm{mg} / \mathrm{mL}$ hygromycin B was used for selection. The observed mitotic stability (95\%) of these transformants was high, and they retained the ability to grow on hygromycin B after five generations on non-selective medium, similar to the mitotically stable transformants of other species of fungi transformed via $A$. tumefaciens (Fitzgerald et al., 2003; Ando et al., 2009; Figueiredo et al., 2010). The expression of the hygromycin B resistance gene was confirmed by PCR in all the transformants and was performed as described in Lunardi et al. (2006). 
The presence of marker genes, as indicated by the expression of green and red fluorescent proteins, as well the selection of transformants using hygromycin B resistance demonstrated that genetic transformation via A. tumefaciens can be used to monitor the colonization of F. proliferatum in the roots and aerial parts of host plants in future studies. The expression of the transformed genes remained stable for some time following genetic transformation, regardless of the presence of a selective medium (Fitzgerald et al., 2003; Knight et al., 2009). The fluorescence was observed in both conidia and hyphae, as was observed by Islam et al. (2012) following the genetic transformation of F. oxysporum by A. tumefaciens. GFP has long been used as a marker in the genetic transformation of fungi (Fang et al., 2006; Müller et al., 2006; Sebastianes et al., 2012; Rodrigues et al., 2013); however, other proteins can also be used with a similar efficiency. The DsRed protein, which showed similar expression to GFP, has been reported in other studies as a good transformant marker for host-pathogen interaction studies (Eckert et al., 2005; Helber and Requena, 2008; Lakshman et al., 2012).

The results in this study show the use of ATMT of $F$. proliferatum for the first time as a tool for random insertional mutagenesis that could be used in future studies to better understand the interactions between the pathogen and soybean roots. This technique allows infection of the host to be monitored and to generate knockout mutants of pathogenicity genes.

\section{Conflicts of interest}

The authors declare no conflict of interest.

\section{ACKNOWLEDGMENTS}

The authors would like to thank Dr. Carlos Labate for providing the strain of $A$. tumefaciens, as well as plasmids and for help in the Agrobacterium-mediated transformation technique.

\section{REFERENCES}

Ando A, Sumida Y, Negoro H, Suroto DA, et al. (2009). Establishment of Agrobacterium tumefaciens-mediated transformation of an oleaginous fungus, Mortierella alpina 1S-4, and its application for eicosapentaenoic acid producer breeding. Appl. Environ. Microbiol. 75: 5529-5535. http://dx.doi.org/10.1128/AEM.00648-09

Aoki T, O'Donnell K and Scandiani MM (2005). Sudden death syndrome of soybean in South America is caused by four species of Fusarium: Fusarium brasiliense sp. nov., F. cuneirostrum sp. nov., F. tucumaniae, and F. virguliforme. Mycoscience 46: 162-183. http://dx.doi.org/10.1007/S10267-005-0235-Y

Aoki T, Scandiani MM and O'Donnell K (2012). Phenotypic, molecular phylogenetic, and pathogenetic characterization of Fusarium crassistipitatum sp. nov., a novel soybean sudden death syndrome pathogen from Argentina and Brazil. Mycoscience 53: 167-186. http://dx.doi.org/10.1007/S10267-011-0150-3

Boller T and He SY (2009). Innate immunity in plants: an arms race between pattern recognition receptors in plants and effectors in microbial pathogens. Science 324: 742-744.http://dx.doi.org/10.1126/science.1171647

Chang KF, Hwang SF, Conner RL, Ahmed HU, et al. (2015). First report of Fusarium proliferatum causing root rot in soybean (Glycine max L.) in Canada. Crop Prot. 67: 52-58. http://dx.doi.org/10.1016/j.cropro.2014.09.020

Covert SF, Kapoor P, Lee M, Briley A, et al. (2001). Agrobacterium-mediated transformation of Fusarium circinatum. Mycol. Res. 105: 259-264. http://dx.doi.org/10.1017/S0953756201003872

de Groot MJA, Bundock P, Hooykaas PJJ and Beijersbergen AGM (1998). Agrobacterium tumefaciens-mediated transformation of filamentous fungi. Nat. Biotechnol. 16: 839-842.http://dx.doi.org/10.1038/nbt0998-839

Díaz-Arias MM, Munkvold GP and Leandro FS (2011). First report of Fusarium proliferatum causing root rot on soybean (Glycine max) in the United States. Plant Dis. 95: 1316-1316. http://dx.doi.org/10.1094/PDIS-04-11-0346 
Eckert M, Maguire K, Urban M, Foster S, et al. (2005). Agrobacterium tumefaciens-mediated transformation of Leptosphaeria spp. and Oculimacula spp. with the reef coral gene DsRed and the jellyfish gene gfp. FEMS Microbiol. Lett. 253: 67-74. http://dx.doi.org/10.1016/j.femsle.2005.09.041

Fang W, Pei Y and Bidochka MJ (2006). Transformation of Metarhizium anisopliae mediated by Agrobacterium tumefaciens. Can. J. Microbiol. 52: 623-626.http://dx.doi.org/10.1139/w06-014

Figueiredo JG, Goulin EH, Tanaka F, Stringari D, et al. (2010). Agrobacterium tumefaciens-mediated transformation of Guignardia citricarpa. J. Microbiol. Methods 80: 143-147. http://dx.doi.org/10.1016/j.mimet.2009.11.014

Fitzgerald AM, Mudge AM, Gleave AP and Plummer KM (2003). Agrobacterium and PEG-mediated transformation of the phytopathogen Venturia inaequalis. Mycol. Res. 107: 803-810.http://dx.doi.org/10.1017/S0953756203008086

Frandsen RJN (2011). A guide to binary vectors and strategies for targeted genome modification in fungi using Agrobacterium tumefaciens-mediated transformation. J. Microbiol. Methods 87: 247-262. http://dx.doi.org/10.1016/j. mimet.2011.09.004

Helber N and Requena N (2008). Expression of the fluorescence markers DsRed and GFP fused to a nuclear localization signal in the arbuscular mycorrhizal fungus Glomus intraradices. New Phytol. 177: 537-548.

Islam MN, Nizam S and Verma PK (2012). A highly efficient Agrobacterium mediated transformation system for chickpea wilt pathogen Fusarium oxysporum f. sp. ciceri using DsRed-Express to follow root colonisation. Microbiol. Res. 167: 332-338. http://dx.doi.org/10.1016/j.micres.2012.02.001

Ivić D, Domijan AM, Peraica M, Milicević T, et al. (2009). Fusarium spp. contamination of wheat, maize, soybean, and pea grain in Croatia. Arh. Hig. Rada Toksikol. 60: 435-442. http://dx.doi.org/10.2478/10004-1254-60-2009-1963

Knight CJ, Bailey AM and Foster GD (2009). Agrobacterium-mediated transformation of the plant pathogenic fungus Verticillium albo-atrum. J. Plant Pathol. 91: 745-750.

Lakshman DK, Pandey R, Kamo KK, Bauchan GR, et al. (2012). Genetic transformation of Fusarium oxysporum f. sp. gladioli with Agrobacterium to study pathogenesis in Gladiolus. Eur. J. Plant Pathol. 133: 729-738. http://dx.doi. org/10.1007/s10658-012-9953-0

Liu $\mathrm{H}$ and Bao X (2009). Overexpression of the chitosanase gene in Fusarium solani via Agrobacterium tumefaciensmediated transformation. Curr. Microbiol. 58: 279-282. http://dx.doi.org/10.1007/s00284-008-9334-2

Liu YG and Chen Y (2007). High-efficiency thermal asymmetric interlaced PCR for amplification of unknown flanking sequences. Biotechniques 43: 649-650, 652, 654 passim. http://dx.doi.org/10.2144/000112601

Lunardi LU, Fier CB, Ashikaga FY, Morioka LR, et al. (2006). Obtenção de mutantes de Aspergillus carbonarius via transformação genética mediada por Agrobacterium tumefaciens. Semina: Cienc. Biol. Saúde 27: 95-104.

Lysøe E, Klemsdal SS, Bone KR, Frandsen RJN, et al. (2006). The PKS4 gene of Fusarium graminearum is essential for zearalenone production. Appl. Environ. Microbiol. 72: 3924-3932. http://dx.doi.org/10.1128/AEM.00963-05

Maciá-Vicente JG, Jansson HB, Talbot NJ and Lopez-Llorca LV (2009). Real-time PCR quantification and live-cell imaging of endophytic colonization of barley (Hordeum vulgare) roots by Fusarium equiseti and Pochonia chlamydosporia. New Phytol. 182: 213-228. http://dx.doi.org/10.1111/j.1469-8137.2008.02743.x

Magnani M, Fernandes T, Prete CEC, Homechim M, et al. (2005). Molecular identification of Aspergillus spp. isolated from coffee beans. Sci. Agric. (Piracicaba, Braz.) 62: 45-49.

Malonek S and Meinhardt F (2001). Agrobacterium tumefaciens-mediated genetic transformation of the phytopathogenic ascomycete Calonectria morganii. Curr. Genet. 40: 152-155. http://dx.doi.org/10.1007/s002940100236

Merlington A, Hanson LE, Bayma R, Hildebrandt K, et al. (2014). First report of Fusarium proliferatum causing dry rot in Michigan commercial potato (Solanum tuberosum) production. Plant Dis. 98: 843. http://dx.doi.org/10.1094/ PDIS-09-13-0919-PDN

Michielse CB, Hooykaas PJ, van den Hondel CA and Ram AF (2005). Agrobacterium-mediated transformation as a tool for functional genomics in fungi. Curr. Genet. 48: 1-17.http://dx.doi.org/10.1007/s00294-005-0578-0

Müller T, Benjdia M, Avolio M, Voigt B, et al. (2006). Functional expression of the green fluorescent protein in the ectomycorrhizal model fungus Hebeloma cylindrosporum. Mycorrhiza 16: 437-442. http://dx.doi.org/10.1007/ s00572-006-0060-y

Mullins ED and Kang S (2001). Transformation: a tool for studying fungal pathogens of plants. Cell. Mol. Life Sci. 58: 2043-2052. http://dx.doi.org/10.1007/PL00000835

Mullins ED, Chen X, Romaine P, Raina R, et al. (2001). Agrobacterium-mediated transformation of Fusarium oxysporum: an efficient tool for insertional mutagenesis and gene transfer. Phytopathology $91: 173-180$. http://dx.doi.org/10.1094/ PHYTO.2001.91.2.173

Nelson PE, Tousson TA and Marasas WFO (1983). Fusarium species: An illustrated manual for identification. The Pennsylvania State University Press, University Park, USA.

Pudake RN, Swaminathan S, Sahu BB, Leandro LF, et al. (2013). Investigation of the Fusarium virguliforme fvtox1 mutants revealed that the FvTox1 toxin is involved in foliar sudden death syndrome development in soybean. Curr. Genet. 59: 107-117.http://dx.doi.org/10.1007/s00294-013-0392-z 
Rodrigues MBC, Fávaro LCL, Pallu APS, Ferreira A, et al. (2013). Agrobacterium-mediated transformation of Guignardia citricarpa: an efficient tool to gene transfer and random mutagenesis. Fungal Biol. 117: 556-568. http://dx.doi. org/10.1016/j.funbio.2013.06.005

Ruiz-Díez B (2002). Strategies for the transformation of filamentous fungi. J. Appl. Microbiol. 92: 189-195. http://dx.doi. org/10.1046/j.1365-2672.2002.01516.x

Sebastianes FLS (2010). Diversidade genética e potencial biotecnológico de fungos endofíticos de manguezais do estado de São Paulo. PhD thesis. Escola Superior de Agricultura Luiz de Queiroz, São Paulo.

Sebastianes FLS, Lacava PT, Fávaro LCL, Rodrigues MBC, et al. (2012). Genetic transformation of Diaporthe phaseolorum, an endophytic fungus found in mangrove forests, mediated by Agrobacterium tumefaciens. Curr. Genet. 58: 21-33. http://dx.doi.org/10.1007/s00294-011-0362-2

Sørensen LQ, Lysøe E, Larsen JE, Khorsand-Jamal P, et al. (2014). Genetic transformation of Fusarium avenaceum by Agrobacterium tumefaciens mediated transformation and the development of a USER-Brick vector construction system. BMC Mol. Biol. 15: 1-15.http://dx.doi.org/10.1186/1471-2199-15-15

Stergiopoulos I, Kourmpetis YAI, Slot JC, Bakker FT, et al. (2012). In silico characterization and molecular evolutionary analysis of a novel superfamily of fungal effector proteins. Mol. Biol. Evol. 29: 3371-3384.http://dx.doi.org/10.1093/ molbev/mss 143

White TJ, Bruns TD, Lee S and Taylor JW (1990). Amplification and direct sequencing of fungal ribosomal RNA genes for phylogenetics. (Innis MA, Gelfand DH, Sninsky JJ and White TJ, eds.). PCR Protocols: a guide to methods and applications. Academic Press, San Diego.

Yorinori JT, Charchar M, D’Avila J, Nasser LCB, et al. (1993). Doenças da soja e seu controle. (Arantes NE and Souza PIM, eds). Cultura da Soja nos Cerrados. Potafos, Piracicaba. 